\title{
PERGESERAN FUNGSI MAMAK KANDUNG DALAM PELAKSANAAN ADAT MINANGKABAU PADA MASYARAKAT JORONG BATU BADINDING NAGARI LIMO KOTO KECAMATAN BONJOL KABUPATEN PASAMAN
}

\author{
Hafizah \\ STKIP Ahlussunnah Bukittinggi \\ hafizah_pipit@yahoo.co.id
}

\begin{abstract}
This study aims to reveal the shifting forms of mother's brother function in the guardianship Batu Badinding community, the cause of the shift in the function of mother's brother biological in the customar practices of the Minangkabau people in the guardianship Batu Badinding community, the impact of the shift in the function of the mother's brother in the implementation of the Minangkabau Customs in guardianship Batu Badinding. This is a case study research. The informant selection technique uses a method (purposive sampling). the results showed that there had been a shift in the function of mother's brother biological in guardianship Batu Badinding community (1) The forms of shifting functions of mother's brother were: (a) in the economic field, (b) in the field of education, (c) in the religious field, and $(d)$ in the field of Custom (e) in the field of marriage. (2) The causes of the shifting of mother's brother biological functions are: (a) lifestyle in overseas, (b) mother's brother prioritizes children and wives, (c) lack of indigenous knowledge of mother's brother (d) low economic level of mother's brother, (e) mother's brother morality low, $(f)$ the influence of values in Islam. (3) The impact of the shift in the function of the mother's brother biological, namely: (a) the mother's brother figure is less respected by the niece, $(b)$ the authority of mother's brother begins to fade in the middle of the community (c) the fading of kinship and social relations between mother's brother and niece, (d) changes in structure and responsibility family answer.
\end{abstract}

Keywords: Mother's brother, Custom and Conflict functions 


\section{Pendahuluan}

Dalam kehidupan sehari hari, manusia selalu dihadapkan pada kebudayaan, setiap hari orang melihat, mempergunakan dan bahkan kadang-kadang merusak kebudayaan itu sendiri (Soekanto, 2004: 171). Menurut Tylor (dalam Soekanto, 2004:172) kebudayaan adalah kompleks pengetahuan, kepercayaan, kesenian, moral, hukum, adat istiadat dan kemampuan-kemampuan serta kebiasaan-kebiasaan yang didapatkan oleh manusia sebagai anggota masyarakat.

Kebudayaan merupakan faktor penting dalam kehidupan manusia. Sebab kebudayaan memberikan arah kepada tindakan dan karya manusia. Kebudayaan yang telah ada akan tetap berjalan meski kadang-kadang wujudnya dapat berubah (Koentjaraningrat 1996: 74).

J.J Honingman (dalam Koenjaraningrat, 1996:74) membuat perbedaan atas tiga gejala kebudayaan yakni:
a. Ideas (gagasan-gagasan)
b. Activities (kegiatan atau tindakan)

c. Artifacts (budaya materi atau fisik)

Ketiga gejala kebudayaan itu pada dasarnya merupakan perwujudan dari cipta karsa manusia sebagai makhluk budaya yang diwarisi dari generasi sebelumnya. Salah satu wujud kebudayaan itu yakni aktivitas yang tercermin pada fungsi "niniak mamak" yang seharusnya "anak dipangku kemenakan dibimbiang" sekarang sudah bergeser sehingga ada kemenakan yang tidak mengenal mamak mereka sendiri karena berbagai faktor.

Secara umum mamak adalah saudara laki-laki ibu, semua saudara laki-laki ibu, baik adik ibu atau kakaknya adalah mamak. Dengan demikian kemenakan adalah anak dari saudara perempuan baik kakak atau adik saudara laki lakinya. Hubungan mamak dengan kemenakan juga alamiah seketurunan atau sesuku. Mamak bersaudara dengan ibu karena itu dia seketurunan sedangkan anak adalah keturunan ibunya, dengan demikian mamak dan kemenakan mempunyai hubungan seketurunan dan juga 
Jurnal Ilmu Budaya, Vol. 16, No. 1 Agustus Tahun 2019

sesuku menurut garis matrilineal. Hal ini sejalan dengan pendapat Rangkuto (1978:6) yang mengatakan bahwa adat Minangkabau mengajarkan bahwa mamak ialah laki-laki yang bertanggung jawab terhadap anak kemenakannya pria dan wanita dari pihak ibu. Dengan demikian seseorang di Minangkabau mempunyai dua pelindung yaitu: Mamak dan Ayah.

Seperti kata-kata fatwa adat (Idrus Hakimy, 2001:51)

\section{Anak dipangku kemenakan dibimbiang anak dipangku jo pancarian kamanakan dibimbiang jo pusako}

anak dipangku kemenakan di bimbing anak dipangku dengan pencaharian kemenakan dibimbing dengan pusaka

Dengan demikian mamak akan berusaha dengan kemampuannya menurut kemungkinan yang ada padanya untuk membimbing dan melindungi kemenakannya dan begitu pula ayah terhadap anaknya. Pada seorang laki-laki minang didalam dirinya melekat dua fungsi yaitu sebagai ayah dan sebagai mamak. Sebagai mamak mempunyai kewajiban dalam memimpin dan bertanggung jawab atas keselamatan saudara-saudara perempuannya beserta anak dan kemenakannya baik dalam urusan adat, harta warisan maupun perkawinan mamak berkewajiban memperhatikan dan menjaga kemenakannya.

Menurut Soekanto (2004:182) kebudayaan terwujud dan tersalurkan dari perilaku manusia. Setiap masyarakat memiliki norma-norma atau aturan-aturan yang kemudian menjadi Adat dari masyarakat dan berfungsi mengatur segala tingkah laku dalam kehidupan mereka. Antara masyarakat yang satu dengan masyarakat yang lain mempunyai norma atau adat istiadat yang berbeda.

Secara tradisional dalam keluarga, laki-laki di Minangkabau berperan sebagai pemimpin dalam keluarga ibunya. Kekuasaan yang berlaku mengharuskan laki-laki mempunyai tanggung jawab untuk menjaga dan melindungi semua saudara perempuannya dan anak dari saudara-saudara perempuannya. Mamak berperan dalam membimbing 
Jurnal Ilmu Budaya, Vol. 16, No. 1 Agustus Tahun 2019

kemenakannya, memelihara dan mengembangkan harta pusaka serta mewakili keluarga dalam urusan keluarga. Mamak berkewajiban membimbing kemenakan dalam bidang adat, bidang agama, dan bidang perilaku sehari-hari. Kalau kemenakan melakukan kesalahan mamak akan ikut malu karena masyarakat akan bertanya siapa mamaknya.

Dewasa ini perubahan sosial telah terjadi di lingkungan masyarakat Minangkabau. Peran mamak mulai terasa berkurang. Mamak lebih berfungsi sebagai bapak dalam keluarga isterinya. Posisi dan peran mamak pun mulai berubah misalnya dalam hal membimbing kemenakannya, seharusnya yang bertanggung jawab dalam hal pendidikan kemenakannya adalah mamak, tapi sekarang peran tersebut lebih banyak diambil oleh bapak (ayah). Hal ini tentu saja berubah dari yang seharusnya, karena di dalam keluarga di Minangkabau peran mamak sangat penting dan sangat dibutuhkan. Posisi dan fungsi mamak pun mulai bergeser, sekarang ini posisi dan fungsi mamak tidak lagi seperti yang semestinya.

Tidak hanya mamak, kemenakan pun sudah tidak sesuai lagi dengan pepatah sebagaimana yang diungkapkan oleh Rangkuto (1978:13-14) "Sudah banyak yang terjadi dimana kemenakan yang menyanggah mamaknya baik ia kemenakan kandung maupun ia kemenakan bertali budi, banyak kemenakan sekarang yang tidak tahu siapa mamaknya, ada kemenakan perempuan yang hendak menikah tidak memberi tahu pada mamak kandungnya lagi, ada kemenakan perempuan yang sudah pandai mencari suami sendiri, ada pula kemenakan yang menghabiskan harta pusaka untuk kepentingan pribadinya, ada kemenakan kini yang sudah jauh hanyut terbawa oleh krisis moral hingga tidak dapat dipintas lagi, banyak lagi fakta yang memalukan dan menyedihkan yang menyimpulkan bahwa kemenakan zaman sekarang kebanyakan sudah tidak mudah menurut lagi baik tentang adat maupun tentang agama”. Fenomena lain juga menjadi bukti bahwa hubungan kekerabatan antara 
Jurnal Ilmu Budaya, Vol. 16, No. 1 Agustus Tahun 2019

mamak dengan kemenakan mulai merosot adalah seperti banyaknya mamak yang pergi merantau menjadi penyebab semakin jauhnya mamak dengan kemenakan, sehingga mamak tidak dapat memenuhi semua kepentingan kemenakan yang menjadi tanggung jawabnya.

Berdasarkan hal-hal di atas maka penulis merasa tertarik untuk melakukan penelitian tentang Pergeseran Fungsi Mamak Dalam Pelaksanaan Adat Minangkabau pada Masyarakat Masyarakat Jorong Batu Badinding Nagari Limo Koto Kecamatan Bonjol Kabupaten Pasaman.

\section{Metode Penelitian}

Penelitian ini menggunakan pendekatan kualitatif. Tipe penelitian ini adalah tipe studi kasus. Studi kasus adalah suatu pendekatan untuk mempelajari, menerangkan atau menginterpretasikan suatu kasus (case) dalam konteksnya secara natural tanpa ada intervensi dari pihak luar (Salim, 2003:93). Tipe studi kasus dalam penelitian ini diharapkan dapat memberikan gambaran yang menyeluruh dan mendalam tentang Pergeseran Fungsi Mamak Dalam Pelaksanaan Adat Minangkabau pada Masyarakat Masyarakat Jorong Batu Badinding Nagari Limo Koto Kecamatan Bonjol Kabupaten Pasaman. Penelitian ini termasuk tipe studi kasus instrinsik dengan model studi kasus tunggal dengan single level analysis.

Teknik pemilihan informan dengan menggunakan motode (purposive sampling). Artinya informan ditentukan secara sengaja atas pertimbangan tertentu bukan secara acak (Faisal, 1990:56). Jumlah informan dalam penelitian ini adalah sebanyak 10 orang masyarakat setempat. Data yang dikumpulkan dari dalam penelitian ini terdiri dari dua jenis data yaitu data primer dan sekunder. Data primer data yang berhubungan langsung dengan objek formal penelitian Pergeseran Fungsi Mamak Dalam Pelaksanaan Adat Minangkabau pada Masyarakat Masyarakat Jorong Batu Badinding Nagari Limo Koto Kecamatan Bonjol Kabupaten Pasaman

Teknik yang dipakai untuk mendapatkan data adalah observasi atau pengamatan, wawancara dan 
Jurnal Ilmu Budaya, Vol. 16, No. 1 Agustus Tahun 2019

dokumentasi. Teknik penjamin keabsahan data merupakan salah satu faktor yang menentukan dalam penelitian kualitatif. Dalam hal ini untuk menjamin dan memperkuat keabsahan data penelitian Pergeseran Fungsi Mamak Dalam Pelaksanaan Adat Minangkabau pada Masyarakat Jorong Batu Badinding Nagari Limo Koto Kecamatan Bonjol Kabupaten Pasaman. Diantara langkah-langkah yang peneliti lakukan diantaranya : 1) perpanjang keikutsertaan, 2) ketekunan pengamatan, dan 3) triangulasi data (Moleong, 2009: 327-330).

$$
\text { Penelitian dimulai }
$$

Desember 2018 sampai 25 April 2019, jadi kira-kira penelitian ini berlangsung sekitar 4 bulan setengah.

\section{Hasil dan Pembahasan}

Masyarakat Minangkabau mempunyai hubungan kekerabatan yang sangat luas, baik antara individu dengan individu, antara individu dengan keluarga, maupun antara satu keluarga dengan keluarga lain. Dengan adanya hubungan seperti itu menjadikan mereka sebagai masyarakat yang kolektif dan masyarakat yang memiliki rasa kebersamaan yang tinggi. Sebagai masyarakat minang selayaknya harus tahu bagaimana sistem kekerabatan yang berlaku di Minangkabau. Sistem kekerabatan menurut pendapat Dt. Bandaro (2004:317) adalah sekumpulan unsur yang secara teratur saling berkaitan sehingga membentuk satu kesatuan atau kelompok, kerabat adalah pertalian keluarga, sedangkan kekerabatan adalah perihal yang berkaitan dengan pertalian keluarga.

Jadi sistem kekerabatan orang minang adalah hubungan yang teratur antara individu di Minangkabau sehingga membentuk satu kesatuan atau kelompok. Kebersamaan ini menjadikan hubungan antara individu dan hubungan antar keluarga sangat akrab, hal ini diungkapkan dalam kato pusako urang minang oleh Dt. Bandaro (2004:318) sebagai berikut:

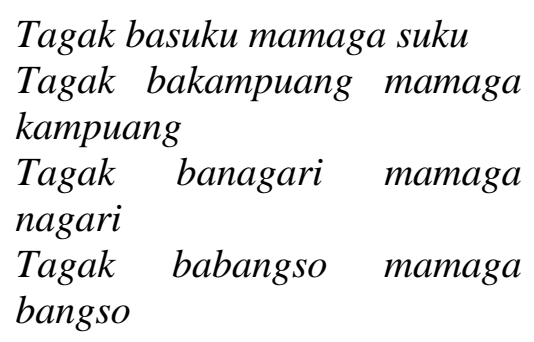

(Berdiri disuku memagar suku, 
Jurnal Ilmu Budaya, Vol. 16, No. 1 Agustus Tahun 2019

Berdiri di kampung memagar kampung,

Berdiri di nagari memagar nagari

Berdiri di bangsa memagar bangsa)

Rasa kebersamaan itu juga diungkapkan oleh pitua urang tuo minang semenjak dahulu kala yaitu sebagai berikut:

Sasakik sasanang, sahino samalu,

Kok ado samo dimakan, kok tido samo dicari,

Barek samo dipikua, ringan samo dijinjiang,

Kabukik samo mandaki, kalurah samo manurun,

Tatilantang samo minum ambun,

Tatilungkuik samo makan tanah,

Laki-laki samalu, padusi sarasan (Dt. Bandaro, 2004:318)

(Sama-sama sakit sama-sama senang

Sama-sama terhina sama-sama malu

Kalau ada sama-sama dimakan, kalau tidak ada sama-sama dicari

Berat sama dipikul, ringan sama dijinjing

Kebukit sama-sama mendaki, kelurah sama-sama menurun Terlentang sama-sama minum embun

Tertelungkup sama-sama makan tanah
Laki-laki sama-sama malu, perempuan satu perasaan).

Dilihat dari perkembangan sejarah masyarakat Minangkabau yang menganut prinsip keturunan ibu atau matrilineal, hubungan kekerabatan antara seseorang anak dengan saudara laki-laki ibunya disebut dengan istilah hubungan kekerabatan mamak dengan kemenakan. Walaupun struktur masyarakat Minangkabau berdasarkan garis keturunan ibu, namun yang berkuasa dalam kesatuan-kesatuan itu selalu orang laki-laki dari garis ibu. Hanya saja kekuasaan selalu didasarkan atas mufakat seperti bunyi pepatah minang "kamanakan barajo $k a$ mamak, mamak barajo ka mufakat". Artinya kemenakan beraja ke mamak, mamak beraja ka mufakat. (Dt. Bandaro. 2004:319).

Secara umum mamak adalah saudara laki-laki ibu, semua saudara laki-laki ibu, baik adik ibu atau kakaknya adalah mamak. Dengan demikian kemenakan adalah saudara perempuan seseorang, hubungan mamak dengan kemenakan juga alamiah seketurunan dan sesuku. 
Jurnal Ilmu Budaya, Vol. 16, No. 1 Agustus Tahun 2019

Mamak bersaudara dengan ibu karena itu dia seketurunan sedangkan anak adalah ketutunan ibunya, dengan demikian mamak dan kemenakan mempunyai hubungan seketurunan dan juga sesuku menurut garis matrilineal. Hal ini sejalan dengan pendapat Rangkuto (1978:6) yang mengatakan bahwa "adat minangkabau mengajarkan bahwa mamak ialah laki-laki yang bertanggung jawab terhadap anak dan kemenakannya pria dan wanita dari pihak ibu".

\section{Posisi Mamak}

Di Minangkabau terdapat dua corak atau bentuk kepemimpinan yaitu pemimpin formal (pemerintah) dan pemimpin non formal. Mamak adalah pemimpin non formal. Ajaran adat Minangkabau dan pandangan hidupnya tertuang dalam bentuk pepatah, petitih dan pituah, serta ungkapan lain yang mengambil contoh dari alam, alam semesta dengan segala unsurnya (Navis, 1984:59).

Niniak Mamak sebagai pimpinan informal dalam masyarakat tradisional ditandai dengan tidak diadakan peresmian pengangkatan pemimpin, juga tidak merupakan jabatan yang diwarisi secara turun temurun berdasarkan garis keturunan darah atau hubungan darah. Kepemimpinan dilahirkan berdasarkan jabatan fungsional seperti mengurus masalah agama, pemerintahan, serta keamanan atau tugasnya sebagai pengamanan negeri di dalam suatu komunitas yang disebut dengan nagari.

Dilihat dari tugas seorang niniak mamak didalam Nagari, dengan kedudukan ini tetap merupakan pimpinan yang melaksanakan tugas dan wewenang serta tanggung jawab yang diberikan oleh kaum, suku atau nagari kepadanya, sehubungan dengan pandangan warga kaum dan sukunya tetap sebagai pimpinan mereka. Peran yang paling utama bagi mamak didalam keluarga ibu ialah sebagai pemimpin dalam keluarga.

Mamak memiliki posisi atau tugas untuk menjaga keamanan dan kenyamanan masyarakat terutama dalam menjaga kemenakannya dan saudara perempuannya. 
Jurnal Ilmu Budaya, Vol. 16, No. 1 Agustus Tahun 2019

\section{Konsep Pergeseran}

Pergeseran menurut Kamus

Bahasa Indonesia (Purwadarminto, 1982:13) berarti peralihan, perpindahan dan pergantian. Sedangkan menurut Gilin dan Gillin (dalam Soekanto, 2004: 304-305) menyatakan perubahan sosial adalah suatu variasi dan cara hidup yang telah diterima dan disebabkan karena perubahan geografis, kebudayaan, dan penemuan baru dalam masyarakat.

Perubahan itu bisa berupa kemajuan (progress) atau mungkin sebuah kemunduran (regres) seperti yang dijelaskan Astrid Susanto dalam (Syamsir. 2003:124) bahwa: perubahan sosial akan mengalami kemajuan (progress) apabila masyarakat bisa menguasai teknologi dan penggunaan penemuan teknologi tersebut mengubah pendapat dan penilaian melalui falsafah hidup baru dan perubahan sosial akan mengalami kemunduran (regres) apabila manusia tenggelam dalam persoalan-persoalan yang dihadapinya dan tidak dapat mengambil sikap atau keputusan terhadap keadaan baru kedalam keadaan itu maka terjadi frustasi.

Dengan demikian dapat disimpulkan bahwa perubahan sosial itu adalah suatu proses modifikasi atau penyesuaian yang terjadi dalam pola hidup antara dua kebudayaan dan kebudayaan yang baru yang mencakup nilai-nilai budaya, pola perilaku, kelompok masyarakat, hubungan-hubungan sosial ekonomi dan kelembagaan masyarakat yang menembus batas ke berbagai tingkat kehidupan sosial masyarakat di karenakan berbagai aspek kehidupan yang selalu berkembang dan terus berubah sesuai perkembangan pengetahuan masyarakat serta teknologi penunjangnya.

1. Bentuk-bentuk pergeseran fungsi mamak pada masyarakat Jorong Batu Badinding Nagari Limo Koto Kecamatan Bonjol Kabupaten Pasaman

Berdasarkan data yang diperoleh terjadi pergeseran fungsi mamak pada masyarakat Jorong Batu Badinding dalam berbagai bidang 
Jurnal Ilmu Budaya, Vol. 16, No. 1 Agustus Tahun 2019

\section{kehidupan diantaranya sebagai berikut: \\ a. Fungsi Mamak dalam Bidang Ekonomi}

Dewasa ini masalah ekonomi merupakan salah satu aspek dalam kehidupan yang memiliki peranan sangat penting demi kelangsungan hidup kita sehari-hari. Sulitnya mencari pekerjaan adalah salah satu persoalan ekonomi yang serius. Hal ini mau tidak mau menjadi masalah yang harus dipikirkan dan dipikul mamak dalam komunitas masyarakat Minangkabau, karena bagaimanapun juga salah satu tugas pokok seorang mamak adalah harus ikut serta memperhatikan dan membantu anak kemenakan demi kelanjutan hidupnya sehari-hari di tengahtengah masyarakat. Mamak sebagai seorang laki-laki Minangkabau mau tidak mau mestilah menjalani dua peran. Pertama sebagai mamak dalam rumah ibunya dan kedua sebagai urang sumando dalam rumah istrinya. Perempuan sebagai pemegang harta pusaka dan laki-laki secara langsung adalah pemilik kekuasaan terhadap harta pusaka sebagaimana yang dinyatakan dalam pepatah adat "haria ninik turun ke mamak, ari turun ke kemenakan". (Amir Syarifudin, 190:1984).

Peranan dan tanggung jawab mamak selama ini ada dalam segala lapangan kehidupan terutama ekonomi. Inilah yang menyebabkan adanya wibawa mamak di depan kemenakannya dan yang menyebabkan menggantungkan harapan pada mamaknya. Namun, pada saat sekarang ini kemenakan lebih tergantung pada ayahnya dari pada mamaknya. Mamak sudah berangsur melepaskan tanggung jawabnya terhadap kehidupan ekonomi kemenakannya.

Peran mamak dalam bidang perekonomian sudah mulai tidak dirasakan lagi. Hal ini dikarenakan mamak lebih memprioritaskan anak isteri, disamping itu mamak sudah jarang yang mengelola harta pusaka keluarga yang hasilnya itu dijadikan untuk membiayai kemenakan. Karena hasil dari pencarian pribadi mamak adalah untuk membiayai anaknya, sedangkan untuk kemenakannya dibiayai dengan hasil pengelolaan harta pusaka misalnya 
Jurnal Ilmu Budaya, Vol. 16, No. 1 Agustus Tahun 2019

sawah dan ladang. Dengan tidak ikut sertanya mamak mengelola harta pusaka menyebabkan kehidupan perekonomian kemenakan tidak ikut menjadi beban mamak, lain halnya jika mamak mampu dan secara sukarela mau membantu kehidupan perekonomian kemenakan.

\section{b. Fungsi Mamak}

\section{Bidang Pendidikan}

Dalam masyarakat minangkabau fungsi dan tugas seorang mamak adalah menjaga saudara-saudaranya yang perempuan, membimbing kemenakankemenakannya serta menjaga harta pusaka.

Terhadap anak kemanakan perempuan bimbingan mamak dalam pendidikan juga meliputi persiapan untuk menyambut warisan dan untuk melanjutkan garis keturunan, termasuk cara-cara membina rumah tangga. Terhadap kemenakan lakilaki, bimbingan itu meliputi didikan untuk memelihara harta pusaka serta mempersiapkan kemenakan laki-laki untuk dapat mewarisi fungsi mamak untuk menjadi pimpinan dalam lingkungannya, baik dalam lingkungan rumah, paruik maupun sukunya (Syarifudin, 1984:200)

Pendidikan adalah sesuatu hal yang penting dan sudah menjadi kebutuhan tersendiri bagi seluruh manusia termasuk bagi masyarakat Jorong Batu Badinding. Sebagai bukti akan hal tersebut, sebagian besar Masyarakat Jorong Batu Badinding berupaya untuk menyekolahkan anak mereka setinggi-tingginya.

Dulu mamak berfungsi dalam hal mendidik kemenakan baik dalam hal etika, cara makan, ataupun memberikan uang untuk sekolah. Namun sekarang masalah pendidikan diberikan sepenuhnya pada orang tua dan guru di sekolah. Sehingga jika anak kemenakan berbuat salah bukan nama mamak lagi yang jelek namun nama orang tua si anak.

\section{c. Fungsi Mamak Dalam Bidang Keagamaan}

Sebagaimana diketahui bahwa masyarakat Minangkabau pada umumnya dan masyarakat Jorong Batu Badinding Nagari Limo Koto khususnya adalah masyarakat yang taat melaksanakan syariat agama 
Jurnal Ilmu Budaya, Vol. 16, No. 1 Agustus Tahun 2019

yang dianutnya yaitu agama Islam.

Agama Islam adalah agama yang diyakini masyarakat sejak lama, sehingga semua aturan-aturan adat yang berlaku didasarkan pada ajaran agama Islam.

Oleh karena itu semua aturanaturan adat yang dianut masyarakat didasarkan kepada ajaran agama Islam. Islam menjadi dasar yang paling utama terhadap aturan adat tersebut. Dengan demikian agama Islam dapat dijadikan salah satu ciri masyarakat Minangkabau. Seandainya ada seseorang yang tinggal di Minangkabau dan tidak beragama Islam, maka dia bukan berasal dari suku bangsa Minangkabau (Amir.B, 1984:53).

Adapun kesimpulan dari fungsi mamak dalam bidang keagamaan adalah sebagai seorang mamak harus bisa mengajarkan kepada kemenakannya apa yang baik dan apa yang tidak baik agar kemenakannya taat melaksanakan syariat agama Islam.

$$
\text { Masyarakat Jorong Batu }
$$

Badinding semuanya beragama Islam dan mereka adalah masyarakat yang taat dalam melaksanakan syariat agama yang diyakini masyarakat sejak lama sehingga aturan-aturan yang berlaku di Jorong Batu Badinding bersandikan pada ajaran agama Islam. Mamak memegang peranan penting dalam pelaksanaan agama kemenakan, mamak sebagai pengayom dan tauladan bagi kemenakan, mamak harus bisa mengontrol bagaimana ketaatan beragama si kemenakan. Namun saat ini karena kesibukan mamak maka yang mendidik anak dalam bidang agama adalah orang tua dan guru mengaji di sekolah.

\section{d. Fungsi Mamak Dalam Bidang Adat}

Kata adat berasal dari bahasa Arab yang secara etimologis berarti kebiasaan yang berlaku berulang kali. Dalam bahasa Indonesia kata adat biasa digabungkan dengan kata istiadat yang juga berasal dari bahasa Arab dengan arti sesuatu yang dibiasakan. Rangkaian kedua kata tersebut dalam pengertian Minangkabau berarti peraturan yang mengatur cara pergaulan masyarakat dengan perorangan serta pergaulan 
Jurnal Ilmu Budaya, Vol. 16, No. 1 Agustus Tahun 2019

antara perorangan dengan sesamanya

(Syarifudin, 1984:140).

Adat lebih dahulu ada di Minangkabau dari pada Islam, namun dalam pembentukan hukum di Minangkabau yang berlaku adalah hukum Islam dengan materinya diresapi dari hukum adat. Maksudnya adalah adat yang telah lebih lama berlaku tetap dijalankan selama membawa manfaat kehidupan umat dan menghindarkan kemudaratan (kerusakan, kesulitan dan keburukan) dari kehidupan umat.

Adat di Jorong Batu Badinding bersendikan pada syarak atau hukumhukum Islam. Syarak akan selalu dipertahankan oleh masyarakat Jorong Batu Badinding dengan cara menjadikan pedoman dalam setiap aturan yang ada di Jorong Batu Badinding termasuk dalam aturan adat. Setiap peraturan yang dikeluarkan di Jorong Batu Badinding selalu meneladani hukum Islam misalnya tentang ketentuan cara berpakaian. Di lingkungan Jorong Batu Badinding masyarakat haruslah berpakaian sopan menutupi aurat sebagaimana yang diajarkan dalam agama Islam.
Dalam masalah adat mamak dituntut untuk tahu dan mengerti adat yang berlaku di Jorong Batu Badinding tapi saat ini lebih banyak mamak yang tidak tahu adat dari pada yang tahu adat sehingga fungsi mamak sudah tidak berjalan sebagaimana mestinya.

\section{e. Fungsi Mamak Dalam Bidang Perkawinan}

Perkawinan merupakan suatu kebutuhan yang bersifat naluriah bagi setiap makhluk hidup. Salah satu tujuan perkawinan adalah untuk membentuk keluarga yang akan melahirkan anak untuk menyambung keturunan. Perkawinan merupakan suatu akad atau perikatan laki-laki dan perempuan dalam rangka mewujudkan kebahagiaan hidup keluarga, yang diliuputi rasa ketentraman serta rasa kasih sayang (Hamid, 2005: 38). Perkawinan martilineal Minangkabau merupakan urusan bersama kerabatnya, mulai dari pencarian pasangan, membuat persetujuan, melaksanakan pertunangan sampai akad nikah dan helat perkawinan selesai dilaksanakan. 
Jurnal Ilmu Budaya, Vol. 16, No. 1 Agustus Tahun 2019

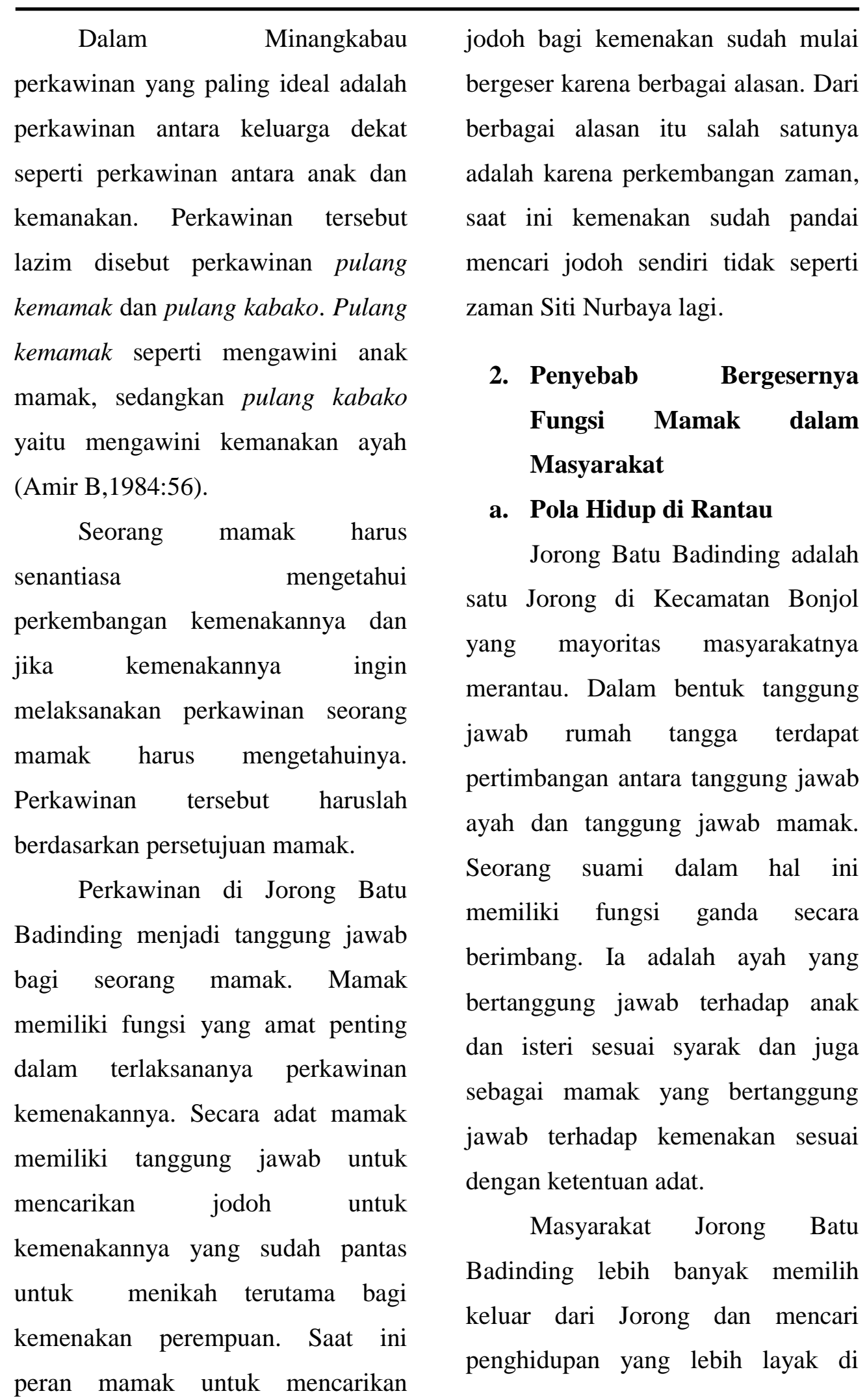


Jurnal Ilmu Budaya, Vol. 16, No. 1 Agustus Tahun 2019

rantau. Sebagian mereka percaya bahwa kehidupan di rantau akan lebih baik dari pada tinggal di Jorong Batu Badinding. Disamping itu dengan merantau berarti secara langsung mamak mulai meninggalkan tanggung jawabnya terhadap kemenakan, karena merantau berarti meninggalkan lingkungan adat Minangkabau sehingga fungsinya sebagai laki-laki yang berperan mamak tidak dapat dijalankan sepenuhnya sesuai tuntunan adat.

\section{b. Mamak}

lebih memprioritaskan anak dan isteri

Mamak yang merantau biasanya membawa sekaligus keluarga yaitu anak dan isterinya. Hal ini menyebabkan intensitas pertemuan antara mamak yang berlaku sebagai ayah lebih banyak dengan anak dan isteri dari pada kemenakannya. Hal ini menimbulkan dampak mamak lebih memprioritaskan anak dan isteri sehingga fungsi mamak sebagai pembimbing bagi kemenakannya mulai berkurang. c. Minimnya pengetahuan adat mamak

Selain silaturrahmi yang kurang antara mamak dengan kemenakan pergeseran fungsi mamak juga disebabkan karena kurangnya pengetahuan adat mamak. Mamak yang lama di rantau sudah bergaul dengan berbagai budaya baru sehingga adat yang melekat padanya adalah adat di tempat dia merantau. Adat di tanah kelahirannya pun mulai luntur.

\section{d. Tingkat}

perekonomian mamak rendah

Faktor lain yang menjadi penyebab bergesernya fungsi mamak adalah karena tingkat perekonomian. Tuntutan ekonomi yang semakin tinggi menyebabkan mamak jadi kurang memperhatikan kemenakannya.

\section{e. Moralitas mamak yang rendah}

Pergeseran fungsi mamak juga dapat terjadi karena moralitas mamak yang rendah sehingga citranya jatuh dimata kemenakan. Oleh sebab itulah kemenakan tidak lagi menyegani dan menghargai mamaknya. Fenomena 
Jurnal Ilmu Budaya, Vol. 16, No. 1 Agustus Tahun 2019

yang sering terjadi di Jorong Batu

Badinding adalah sebagian mamak yang menggunakan harta pusaka untuk kepentingan pribadi bahkan ada yang sampai menggadaikan dan menjualnya padahal menggadaikan harta pusaka adalah sesuatu yang tabu bagi mamak karena fungsi mamak terhadap harta pusaka adalah sebagai pengelola.

\section{f. Pengaruh nilai-nilai dan} hukum Islam

Ajaran Islam telah mewarnai tingkah laku dan amal perbuatan suku bangsa Minangkabau termasuk masyarakat Jorong Batu Badinding. Tingkah laku dan kebiasaan yang telah melembaga itu dasar atau sendinya adalah ajaran agama. Adat bersendi syarak. Syarak bersendi kitabullah. Namun, konsep ini ternyata menyebabkan perbenturan baru. Dalam ketentuan adat posisi laki-laki Minangkabau adalah sebagai mamak yang memiliki tanggungjawab penuh terhadap kemenakan. Namun dalam Islam tanggungjawab penuh seorang lakilaki adalah pada anak dan isterinya. Laki-laki Minangkabau berada pada posisi rumit dan akhirnya pada tataran realitas laki-laki Minangkabau lebih cenderung memilih sebagai seorang ayah daripada sebagai seorang mamak.

\section{Dampak pergeseran fungsi} mamak dalam keluarga

Berdasarkan deskripsi data yang diperoleh di lapangan, maka terjadi pergeseran fungsi mamak yang menyebabkan dampak-dampak tertentu. Agar lebih rinci dapat diidentifikasi dampak dari pergeseran fungsi mamak dalam keluarga pada masyarakat Jorong Batu Badinding sebagai berikut :

\section{a. Figur mamak kurang disegani kemenakan}

Kurang berfungsinya mamak terhadap kemenakan menjadikan kemenakan kurang menyegani mamaknya. Hal ini dikarenakan kemenakan merasa tidak perlu menghormati mamak karena mamak tidak telalu berpengaruh dalam kehidupannya. Ketika seorang mamak dibutuhkan perannya oleh kemenakan dan mamak tidak dapat mewujudkan, maka citra mamak dimata kemenakan akan buruk 
Jurnal Ilmu Budaya, Vol. 16, No. 1 Agustus Tahun 2019

sehingga menyebabkan kemenakan tidak terlalu segan kepada mamaknya.

\section{b. Wibawa mamak mulai} luntur di tengah masyarakat

Kurang berfungsinya mamak terhadap kemenakan bisa menyebabkan kemenakan tidak terkontrol dengan baik. Kontrol mamak sangat dibutuhkan demi kebaikan kehidupan kemenakannya. Jika seorang kemenakan melakukan kesalahan maka yang pertama kali dipertanyakan oleh masyarakat sekitar adalah siapa mamaknya? Hal ini menjadi pembuktian kalau mamak bertanggungjawab terhadap tindakan apa saja yang dilakukan oleh kemenakan, baik itu tindakan yang benar maupun tindakan yang salah. Kalau kemenakan melakukan suatu yang benar maka mamak akan mendapat pujian dari masyarakat, sebaliknya jika kemenakan melakukan kesalahan, maka mamak akan ikut malu dan menjadi bahan gunjingan di tengah masyarakat.

\section{c. Lunturnya kekerabatan dan renggangnya hubungan}

sosial antara mamak dan kemenakan.

Mamak yang merantau biasanya jarang pulang kampung, kalaupun ada biasanya hanya pada momen puasa Ramadhan atau lebaran Idul Fitri. Jarangnya pertemuan antara mamak dan kemenakan menyebabkan hubungan antara keduanya tidaklah dekat, silaturahmi tidak berjalan dengan baik dan harmonis. Hubungan kekerabatan yang seharusnya terjalin sangat erat mulai merenggang.

d. Perubahan struktur dan tanggung jawab keluarga serta konflik yang berkepanjangan antara kemenakan dan mamak kandung

Telah terjadi perubahan struktur kekuasaan di dalam keluarga, seharusnya yang berkuasa dalam keluarga adalah mamak tetapi karena mamak merantau maka terjadi peralihan kekuasaan kepada sumando atau ayah dari kemenakan. Fungsi atau peran mamak mulai kurang dirasakan sehingga segala hal yang berhubungan dengan kemenakan 
Jurnal Ilmu Budaya, Vol. 16, No. 1 Agustus Tahun 2019

diurusi oleh sumando atau ayah dari kemenakan. Perubahan struktur kekuasaan dalam keluarga di Jorong Batu Badinding antara lain disebabkan karena: (1) mamak yang merantau berarti meninggalkan wilayah asal dan menempati wilayah yang baru ini juga berarti meninggalkan tanah pusaka berupa ulayat kaum yang dahulu digunakan sebagai sumber utama perekonomian keluarga (2) mamak yang merantau berarti pindah dari lingkungan sosial yang lama ke lingkungan sosial yang baru dan hidup berdampingan dengan suku-suku lain ini menjadi peluang terjadinya akulturasi.

Salah satu teori yang menganalisis tentang bentuk pergeseran fungsi mamak yaitu teori evolusi (Soekanto, 2004: 311-313) Perubahan evolusi merupakan perubahan sosial yang terjadi dalam proses lambat, dalam waktu yang cukup lama dan tanpa ada kehendak tertentu dari masyarakat yang bersangkutan. Perubahan ini berlangsung mengikuti kondisi perkembangan masyarakat, yaitu sejalan dengan usaha-usaha masyarakat memenuhi kebutuhan kehidupan sehari-hari. Dengan kata lain perubahan sosial terjadi karena dorongan usaha-usaha masyarakat guna menyesuaikan diri terhadap kebutuhan hidupnya dengan perkembangan masyarakat pada waktu itu (Syani, 1994:167). Pergeseran fungsi mamak dalam pelaksanaan adat MinangKabau pada masyarakat Jorong Batu Badinding Nagari Limo Koto Kecamatan Bonjol Kabupaten Pasaman merupakan proses perubahan lambat karena beberapa kondisi sehingga fungsi niniak mamak yang seharusnya memperhatikan kebutuhan kemenakan namun karena perkembangan zaman dan tuntutan hidup menyebabkan fungsi tersebut luntur dan sepenuhnya diemban oleh para orang tua mereka.

Selain itu, Teori Konflik Coser (dalam Poloma, 2004: 111) yang mengatakan bahwa konflik berasal dari kekecewaan terhadap tuntutantuntutan khusus yang terjadi dalam hubungan dan dari perkiraan kemungkinan yang ditujukan pada objek yang dianggap mengecewakan. Pergeseran fungsi mamak kandung ini dapat mengakibatkan konflik 
Jurnal Ilmu Budaya, Vol. 16, No. 1 Agustus Tahun 2019

yang berkepanjangan dari kemenakan

terhadap mamak atau kakak perempuan dengan adik atau kakak laki laki nya karena kekecewaan yang mendalam dari tuntutan fungsi mamak yang seharusnya mereka jalankan namun tidak berfungsi sama sekali.

\section{Penutup}

Secara umum dapat disimpulkan bahwa bergesernya fungsi mamak kandung pada masyarakat Jorong Batu Badinding ini karena banyak mamak yang sudah merantau jauh meninggalkan kampung kelahiran. Mamak terpisah jarak dan waktu dengan kemenakan sehingga silaturrahmi mamak dengan kemenakan tidak berjalan dengan baik. Selain itu, pengetahuan mamak yang minim tentang fungsinya dalam keluarga juga menyebabkan figur mamak kurang disegani kemekanan. Wibawa mamak pun mulai luntur di tengah masyarakat. Lunturnya kekerabatan serta renggangnya hubungan sosial antara mamak dan kemenakan menyebabkan fungsi mamak yang dulunya mencarikan pasangan hidup untuk kemenakan, menjadikan sandaran hidup bagi kemenakan, tempat mengadu, sekarang sudah tidak ada lagi. Hal ini memicu terjadinya konflik yang berkepanjangan antara kemenakan dan mamak kandung serta antara saudara perempuan dengan adik atau kakak laki lakinya.

Berdasarkan hasil penelitian, peneliti menyarankan hal-hal sebagai berikut:

1. Mamak seharusnya bisa membina ahklak kemenakan dengan baik dan benar, membimbing kemenakan dan menasehati untuk mendapatkan pasangan hidup yang baik menurut agama, mamak menjadi tempat mengadu bagi kemenakan dalam segala hal sehingga dengan begitu dapat mempererat dan memperdekat antara mamak dan kemenakan sehingga falsafah Minang anak dipangku

kemenakan dibimbiang dapat terealisasikan lagi.

2. Diharapkan hasil penelitian ini dapat menjadi bahan masukan yang bermanfaat bagi pihakpihak terkait seperti niniak 
Jurnal Ilmu Budaya, Vol. 16, No. 1 Agustus Tahun 2019

$\begin{array}{llr}\text { mamak agar } & \text { dapat } \\ \text { menghidupkan } & \text { kembali } \\ \text { peranan } & \text { lembaga-lembaga } \\ \text { sosial yang } & \text { ada } & \text { dalam } \\ \text { pemerintahan } & \text { nagari } & \text { untuk } \\ \text { meningkatkan } & \text { keharmonisan } \\ \text { dalam lingkungan masyarakat. }\end{array}$

\section{Daftar Pustaka}

Amir, B. Dkk 1984. Dampak Modernisasi Terhadap Sistem Kekerabatan Minangkabau. Proyek IDKP Sumbar 19831984.

Abdulsyani. 1994. Sosiologi Skematika, Teori, dan Terapan. Jakarta: Bumi Aksara

Dt. Bandaro, Latief. 2004. Minangkabau Yang Gelisah. Bandung: Lubuk Agung

Faisal, Sanapiah. 1990. Penelitian Kualitatif: Dasar-dasar dan aplikasi. IKIP Malang: Y A3 Malang.

Hakimy, Idrus. 1984. Rangkaian Mustika Adat Bersendi Syarak di Minangkabau. Bandung: Remaja Karya.

Hamid, Sarong. 2005. Hukum Perkawinan Islam Di Indonesia. Banda Aceh: Yayasan PeNa.

Koenjaraningrat. 1996. Pengantar Antropologi I. Jakarta: Rineka Cipta.
Moleong. Lexy. J. 2009. Metode Penelitian Kualitatif. Bandung: PT Remaja Rosdakarya. Edisi Revisi.

Navis, A.A 1984. Alam Takambang Jadi Guru Adat Budaya Minangkabau. Jakarta: Gramedia.

Poerwadarminta. 1982. Kamus Besar Bahasa Indonesia. Jakarta: Balai Pustaka.

Poloma, M. Margareth. 2004. Sosiologi Kontemporer. Jakarta: Raja Grafindo Persada.

Rangkuto, N. M. 1978. Lembaran Adat Minangkabau" Hubungan mamak dengan kemenakan dahulu dan sekarang". Bukittinggi: Lestari.

Salim, Agus. 2003. Teori dan Paradigma Penelitian Sosial. Semarang: PT. Tiara Wacana.

Soekanto, Soerjono. 2004. Sosiologi Suatu Pengantar. Jakarta: PT. Raja Grafindo Persada.

Syarifudin, Amir. 1984. Pelaksanaan Hukum Kewarisan Islam Dalam Lingkungan Minangkabau. Jakarta : Gunung agung. 